\title{
Deleuzian Reading of Nomadology, War Machine and Transferring from Being to Becoming in Mahmoud Dowlatabadi's Kalidar
}

\author{
Fataneh Zaheri \\ Islamic Azad University, Karaj Branch, Iran \\ E-mail: fatan_z@yahoo.com
}

\begin{abstract}
Received: 19-11-2015
\end{abstract}
Published: 01-05-2016
Accepted: 03-02-2016

doi:10.7575/aiac.ijalel.v.5n.3p.69
Advance Access Published: March 2016

URL: http://dx.doi.org/10.7575/aiac.ijalel.v.5n.3p.69

\begin{abstract}
Kalidar is the novel which has brought Mahmoud Dowlatabadi, an Iranian author, a great honor. It has been considered the second longest novel in the world. There are more than one hundred characters in the novel. The nomad life can be the most significant depiction of the story. However, it has been reviewed and studied from other different approaches and point of views. Analyzing the novel from Deleuzian point of view can be the most complicated reading since it explores rhizome, deterritorialization, reterritorialization as well as nomadology and war machine. All in all, the transforming from being to becoming is the consequence of the nomad life which is analyzed through war machine.
\end{abstract}

Keywords: War Machine, Nomadology, Deterritorialization, Reterritorialization, Rhizome, Being, Becoming

\section{Introduction}

Kalidar (1986) is the second longest novel in world which can be considered Mahmoud Dowlatabadi's best novel he has ever written. Dowlatabadi who is one of the most prominent Iranian authors has written a great number of novels among which Kalidar has been written on work, life and nature as the author says. According to Mahmoud Dowlatabadi, it is a story of bravery in which he illustrates the tragic fate of the Iranian peasantry and the nomadic tribes in a period of political power based on actual events. Perhaps among all distinguished Iranian authors, Mahmoud Dowlatabadi is the one who draws the attention of readers to the nomad life and nomadism through which the remarkable character of Gol Mohammad is portrayed. This novel is nearly three thousand pages in five volumes. The story pictures the life of a nomadic family faced with hostility of neighboring villages despite the similarity of their cultures in Sabzevar, Khurasan which is a Province in Iran. Unlike the other analysis on Kalidar, it can be studied from the view point of Gilles Deleuze who introduced Nomadology and War Machine as well as rhizome, deterritorialization, reterritorialization and more importantly transforming from being to becoming.

The story starts with a Kurdish young woman who rides her horse to the city in order to visit her father and fiancé who have been imprisoned. They are accused of cooperating in murder. Maral and her mother have a difficult life due to drought and famine while her father is in prison. Maral's mother dies as a result of a serious illness. Consequently, Maral becomes alone which makes her decide to live with her paternal aunt named Belqeys. She is Kalmishi's wife and lives in different parts of Kalidar with her family. Belqeys has three sons, Khan Mohammad, Gol Mohammad, Beyg Mohammad and one daughter, Shiroo each one of whom makes the story more challenging. Belqeys and her family accept Maral as well. During the time Maral lives with Kalmishi's family different events happen that lead the story to a big tension. Kalmishi's family are faced with a tough situation through which a bad disease breaks out among their cattle. They are in despair. Their sheep start to die one after another which is a bad message for the Kalmishis. Therefore, Gol Mohammad decides to go to the city to ask the local government for help. But unfortunately, they refuse to help him. The more he requests, the worse they behave. In other words, they ignore Gol Mohammad and his problem. Unlike the whole disappointment he has, he goes to the head of the neighboring village to borrow some money and wheat. Also, Shiroo who is in love with a man named Mahdarvish runs away from her parents' house and marries him without her parents' permission which makes her be abandoned from her family. At the beginning of fall, Kalmishi's family move to a new seasonal pasture in order to find fresh grazing grounds. A lot of livestock die. As result of death of sheep, poverty, lack of food and money, Gol Mohammad and Beyg Mohammad have to carry firewood to the city to make money and support their family. Gol Mohammad and Maral fall in love with each other that ends up their marriage while Gol Mohammad is already married Zivar who is infertile and unable to give birth to babies. The worst thing starts in their life when two sergeants go to Kalmishi's tents to collect tax regardless the drought, lack of food and money with which Kalmishi's family are faced. They try to force them to pay tax or bribe them. Despite all the discussion they have, the sergeants do not consent on considering the trouble Kalmishi's family gets into. Eventually, they decide to take Gol Mohammad to the local government in the city for not paying tax. Gol Mohammad is sent into a rage and decides to kill both of them which leads Gol Mohammad to be killed at the end of the story. 


\section{Nomadology in Kalidar}

According to Gilles Deleuze, Nomadology is a concept concerned with nomadic distribution and the idea of nomad versus nomos. The nomad is shaped by an identity of being that is not connected to or bound by territory. Nomadology permits us to ask questions about the politics of location, the identities of the self and the others and the relevance of both defined and undefined identities.

As we read in the story: "A nomad is like an eagle. He is free. Wherever they are trapped and made to be cooped up so that he cannot see the sun and smell the breeze, the way he cannot hear all strange and familiar sounds of desert, he is deposited in sadness" (14). It is exactly the life of Abdoos, Delavar, and Khan Mohammad, respectively Maral's father, fiancé and cousin who have been imprisoned. They are the nomads who have always been free. They are not bound by territory.

Gol Mohammad who is imprisoned due to being accused of killing two sergeants is talking to his uncle as: "I will not stay here, uncle. I will escape," (983). Prison is a territory which restricts him from moving, working and freedom. On the other hand, he gets to know Sattar, a shoemaker traveling around to make money, better than before. Someone who helped him escape from the jail. In other words, we realize that how these people identify each other. Learning more about Sattar seems to be different, undefined identity. "At this moment, Gol Mohammad thinks about everything, but he always finds himself behind a wall through which he must escape. A lot of things cross his mind. All his dreams remain behind a tall wall, though. His mind only was wandering on freedom..." (987-988).

Mohamud Dowlatabadi depicts that: "In the eye of a nomad, nothing is more natural than nature. river, plain, star, horse, sky and sunset. But whatever looks ordinary and normal in the eyes of the nomads has a strange relationship with their spirit. This connection is not only the result of a wide variety of beauty in nature but also connection of hand and mouth of the nomad" (75). Deleuze brings up the concept of "Nomad Science" in his book. A Thousand Plateaus (1980), which counterpoise to a companionate concept coined "State Science". These terms offer two distinct, incommensurable ways of thinking about bodily matter and embodied form. Nomad Science emphasizes the malleable, fluid and metamorphic nature of being, while State Science conceptualizes being as solid essential and unchanging. In the first pages of Kalidar, Maral is going to the prison in order to visit her father and fiancé. A woman who has ridden her horse from long distance, a Kurdish woman who had put harness of her black horse on her shoulder, is going to nazmieh (police station). Maral can be considered as fluid and malleable. She decides to leave a place where she grew up in due to not having anyone there anymore. A place in which she had lost her mother as a result of drought and then disease. She has ridden her horse as a determined and decisive woman. But on the other hand, the sergeant guarding the prison is solid and unchanging.

In his book, Nomadology: The War Machine, Deleuze explains: "It would seem that a whole nomad science develops eccentrically, one that is very different from the royal or imperial sciences. Furthermore, this nomad science is continually "barred" inhibited or banned by the demands and conditions of State Science" (19). He explains more: "the fact is that the two kinds of science have different modes of formalization, and State Science continually impose its form of sovereignty on the invention of nomad science" (19).

In Kalidar, those two sergeants who stand for state science impose their power on Kalmishi's family in order to make them pay tax. They do not even understand what problems Kalmishi and his family are faced with. Also, they are eager to molest Zivar, Gol Mohammad's first wife. "Our government, God perdures and supports it, comes to us whenever they want to collect tax. They are asleep at the time of disease and calamities. When you ask government for help, they kick you out of their offices. Now you are here" (592). Dowlatabadi portrays the way the nomads are discriminated and how they are treated brutally which ignites the first spark of war machine in the hearts of the nomads.

The way houses are built in Kalidar is the point which must be noticed: "This is Sozandeh exactly like the way it was described on the way to Neyshabour, a small village with short walls. All have been renovated with walls which have separated those dark and dingy houses. It seems that those houses have been scattered irregularly, each house in one direction. One overlooks Mecca, another in the direction of sunset and the other one in direction of sunrise. Each one is small and cramped. It is the most irregular place she has ever seen" (41). The life of nomad has been described as piece of music. It elevates the soul of the person playing music which is conceived in terms of the way is played. Movement to different places lifts up the spirit of a nomad as well. It is the only way to be promoted and move from one spiritual stage to another. These are the points that determine paths which is between two points. The paths which determine the nomad life. They move in order to find water, food, and above all to find life. In other words, the nomads move to create a real life. On the whole, the nomad life can be defined as moving and finding a new place to live. In fact, the nomad's life is involved in moving even though they are faced with a lot of problems.

\section{Reterritorialization and Deterritorialization in Kalidar}

According to Deleuze, the deterritorialization results from movement of nomadic waves or flows. It defies structures that focus on a central point, instead of moving away from the center, creating a new center, depending and returning, ebbing and flowing in relation to no one central point (A Thousand Plateaus, 53-54). In Kalidar, the nomads move from one place to another and again return back. They move around an area called Kalidar to find fresh pastures on which their cattle, sheep to graze. "The Kalmishi's both men and women, separated from each other, being fed up with themselves. Each one of them is standing somewhere or sitting down. In the absence of Gol Mohammad, they had moved to their cattle Kalateh Siah. Their sheep were sleeping near the narrow stream. A lot of sheep and goat's skin was piled up" (360). 
Deleuze and Guattari in their book, What is Philosophy?, postulate that deterritorialization can be physical, mental or spiritual (A Thousand Plateaus, 68). Mahmoud Dowlatabadi brings this to attention: "This desert has been such things many times, love is like one of those desert winds when it comes, it blinds the eyes. You cannot see anything, you prefer to follow your heart. I've mentioned both of you. That is true, you have a fiancé, but you cannot hide your feeling" (110)., The deterritorialization which indicates spiritual and emotional movement is obviously indicated. In addition, spiritual reterritorialization is portrayed as well: "From then on, Ghadir found himself. It seems that he found a dear lost on in himself. Ghadir has found Ghadir. Then he tried to find his position such as an individual, a dependent body on others" (2025). This returning to oneself is reterritorialization which occurs spiritually. Once human abandons his or her own identity, apparently there would be nothing without these movements since it helps to discover your being when reterritorialization occurs. Mahmoud Dowlatabadi writes about Shiroo, Kalmishi's daughter who is thinking about moving out of her parents' house. A place which is fixed. In other words, she is going to escape, to leave her family and follow her heart to marry someone who is firmly refused by Shiroo's family. Shiroo follows a path in her life which is a movement to renew herself through the troubles she gets into. A path between two points, her parents' house and the place where she lives with her husband."It is not possible to be calm, the heart beat is fast. The blood circulates hastily. The eyes are in despair to keep open. The thoughts are wandering and the ears hear any little tiny sound. Night which escapes from its shadows is running. Shiroo gets up secretly like a snake and takes the way of the desert" (129). She runs away in order to live in another place with someone with whom she is in love. On the other hand, after being away from her parents' house for a while, Shiroo burns with the desire of moving back home due to not having a happy married life. Being in calamity, having hardships and being deprived of a life she had dreamt about persuade her to desert. The temporal deterritorialization which shatters all her hopes and dreams makes her a new person with a different perspective. Fortunately, her mother supports her to return back home, to her motherland which is reterritorialization in Shiroo's life. "Belqeys and Shiroo were going home in the dawn. They were both exhausted. Shiroo was full of hatred. She was upset and miserable. "I wish you had not given birth to me, Mom," Shiroo said" (1770). The nomad moves and lives in one place in a short time as their territory. They change the places to find the better one. They do not remain in one place. Their life depends on their movement. "Beyg Mohammad left the place suddenly. He didn't want Sabroo to hug him. It was not appropriate for men to hug each other. Men of desert should not be soft hearted. He looked down and went toward the mountain" (368).

\section{Nomadology and Rhizome in Kalidar}

According to Deleuze 'rhizome' is the connection between objects, people, places and people. A chain of events that links people to each other. In the first part of Kalidar, Maral who moves to Sozandeh where her aunt and her family on her father's side live in order to start a new life with them. A rhizome ceasely establishes connections between semiotic chains, organizations of power, and circumstances relative to the arts, sciences, and social struggles (A Thousand Plateaus,7) Maral's living with her paternal's family, the social struggles Gol Mohammad is involved in and the connections among these people are the evidence for rhizome. Dowlatabadi picures rhizome by how Shiroo and Maral start a close relationship through the events happening to them or how Maral is connected to Gol Mohammad or the friendship between Gol Mohammad and Sattar. In the last volume of this novel there is a great connection between Gol Mohammad and other people who start to support him and form a big and strong chain. As Deleuze claims in his book, multiplicity is one principle of rhizome. It is only when the multiple is effectively treated as a substantive, "multiplicity" that it ceases to have any relation to the one as subject or object, natural or spiritual reality, image and world. A multiplicity has neither subject nor object only determinations, magnitudes, and dimensions that cannot increase in number without the multiplicity changing in nature (A Thousand Plateaus, 8).

Deleuze explains that a rhizome cannot be cut, it may be broken, but it will always begin growing on another line, old or new. At the end of Kalidar, Gol Mohammad, Khan Mohammad, Beyg Mohammad, Zivar and all people who were standing next to him are killed except for Khan Mohammad who is the oldest brother and Gol Mohammad's son among men. Khan Mohammad was already asked to remain alive to revenge their blood because they wanted someone to continue their way. In other words, they need someone to grow the rhizome on an old line. On the other hand, we see Maral with her son going back to their place with Mara's horse which used to belong to Gol Mohammad. Her son who is only about three years old can be considered as part of rhizome to develop and form a new party to avenge her father's blood. In fact, Gol Mohammad's son is a new line on which a new rhizome starts to grow. Not choosing name for Golmohammad's son is a proof for beginning a new rhizome. In his book, A Thousand Plateaus, Deleuze writes there are no points or positions in a rhizome such as those found in a structure, tree or root. There are only lines (8). "We are the nomads, Shiroo. Life of a nomad depends on their steps. We will die if we cannot walk (1770). Rhizome moves and produces, it grows and helps to grow new links. It enhances the desire to grow and be productive.

\section{War Machine and Transferring from Being to Becoming}

In Kalidar, Gol Mohammad started a riot, a kind of civil disobedience. He stated to stand against local government only for defending justice which has never been come to an account in his area. His family has been the victim of injustice. The first step he takes is to kill two sergeants and burn their bodies. He picks up their guns and it is the beginning of a protest against local government. "Snow, desert, the gleam of the guns shinning. There was a struggle within Gol Mohammad, a temptation, the shininess of the guns has taken his peace away. The allurement of conjecture, being under pressure of desire, injustice, poverty, and capability, acrimoniousness, causticity, resentfulness. Scornfulness of a nomad, a nomad man! How important is this world to you? You love all this world, but three things are the most 
important ones to you that can't be ignored: gun, woman, and horse. A woman's glance, the shininess of a gun and incursion of horse persuade you to praise. Gun, Maral, Gharehat" (604).

Deleuze comes to introduce 'becoming'. In his book, A Thousand Plateaus, Deleuze illustrates that becoming is a process of change, flight, or movement within an assemblage. The process of becoming serves to account for relationships between the discrete element of the assemblage. In becoming one piece of the assemblage is drawn into the territory of another piece, changing its value as an element and bringing about a new unity (172). Mahmoud Dowlatabadi, brings assemblage and becoming in Kalidar through Gol Mohammad and all his properties and relationships with people around him. For example, how Gol Mohammad could get a ride on Gharehat, Maral's horse. "There was no opportunity to fear of anything now he could grasp the ear of animal and pull tight. He could jump on the saddle and get control of him. He had no more energy just thinking about controlling him (97).

Deleuze writes: "Bloodletting, immediate killing, run country to the unlimited usage of violence that is to its economy.... The economy of violence is not that of the hunter in the animal raiser, but that of the hunted animal. In horseback riding, one conserve the kinetic energy, the speed of the horse, and no longer its proteins (the motor, and no longer the flesh). Whereas in the hunt the hunter's aim was to arrest the movement of wild animality through systematic slaughter, the animal breeder conserving it, and, by means of training, the rider joins with this movement, orienting it and provoking its acceleration" (Nomadology: War Machine, 66). In Kalidar, we read about the time when Gol Mohammad is trying to ride Mara's horse, Gharehat which only gives a ride to its owner, Maral. "There was no time to fear. When death arrives you have no time to even a wink. A dare becomes stronger, the strength is released. Gol Mohammad was burning in fire from excitement. He was in a bad trouble. If he delayed, he would be smashed under the horse shoes of Gharehat. Not only was the horse fighting with his horseshoes but he was fighting with his teeth" (94). In another part of Kalidar, Mahmoud Dowlatabadi portrays Maral who decided to stand next to her husband. She had a gun and wanted to support Gol Mohammad. "No, Maral has changed. Although she got used to living in misery and hardship, she was still softhearted and her youth could be offended easily. Most of all, she had bandolier over her shoulder and across her chest to carry a lot of bullets. She rode her horse pedal to pedal to Gol Mohammad's, but she found it horrible to live without her husband" (2384).

In Deleuze and Politics, it is written that war is not a basic principle of Deleuzian social theory, but a result of the inevitable conflict between two contradictory modes of being (114). Conflict between Gol Mohammad and government is obvious. "Look Gol Mohammad, what is your life coming to? They are misusing you and you are still silent and say nothing. Workhorse, you only listen till what they want to do. You flatter, you bow and you belittle yourself. You look like those itinerant singers and dances to give a smile at them, folder your arms and on your chest in front of them. You behave that way seem you owe them, "Gol Mohammad muttered" (Kalidar, 596). Here we see the start of this conflict which leads Gol Mohammad to be killed at the end of story.

\section{Conclusion}

There was an attempt to highlight nomadology and war machine introduced by Deleuze in the Iranian novel, Kalidar. The illumination of the notion of rhizome and two other terms reterritorialization and deterritorialization in this novel is the outstanding point of the novel which ends up a big change in the main character of the novel, Gol Mohammad. War machine is formed by the minority of people who are the target of discriminations and suppressed by the government. In fact, this machine is formed in order to stand up for the rights which are taken away by the power of State Apparatus. It follows the line of flight in order not to be ruled. On the other hand, the notion of rhizome which is against the vertical growth of government grows as a line exactly like the branches of a tree. It can be considered as the connection between people to oppose the ruler as we read in Kalidar. The tragic life of the Kalmishis is portrayed as the life of a nomad clearly. Although they work hard and provide the needs of people living in the city, they are always overlooked by the same people. In the case of emergency such as disease among their sheep, they receive no help from the government who is responsible for the life of everyone in the society. On the contrary, these nomads are forced to tax while they are always ignored. Through Gol Mohammad's attempt, war machine emerges. This machine creates rhizome which connects people together. At the end of the novel Gol Mohammad finds himself in a tough situation. To put it simply, he has two ways, one way leads him to be killed with pride and joy, but another way makes him kneel before local fascist and government which ends up being killed spiritually. Eventually, he decides to give his head and be killed which represents transforming from being to becoming.

\section{Reference}

Deleuze, G., \& Guattari, F. (1986). Nomadology: The war machine (p. 1). New York: Semiotext (e)

Deleuze, G., \& Guattari, F. (1987). A thousand plateaus: Capitalism and schizophrenia. Bloomsbury Publishing. Deleuze, Gilles. Anti-oedipus. A\&C Black, 2004.

Deleuze, G. (1986). Kafka: Toward a minor literature (Vol. 30). U of Minnesota Press.

Dowlatabadi, Mahmoud. (1986). Kalidar, Tehran, Farhang moaser.

Mirabedini, Hassan. (1998) One Hundred Years of Writing Fiction. Tehran: Nashr Cheshmeh, Patton, P. (2002). Deleuze and the Political. Routledge. 